\begin{tabular}{llrr}
\hline \hline Volume: & 2 & E-ISSN: & $2655-1942$ \\
Number: & 2 & Terbitan: & Oktober 2019 \\
Page $:$ & $168-182$ & & \\
\hline
\end{tabular}

\title{
Validitas Peraturan Daerah Yang Bernuansa Syariah Dalam Bingkai Otonomi Daerah (Antara Harapan dan Kenyataan) Sebagai Contoh Provinsi Gorontalo dan Provinsi Aceh
}

\author{
Kamarudin H. Dunggio, Johan Jasin \\ Program S2 Ilmu Hukum, Universitas Negeri Gorontalo \\ Email:kamarudindunggi92@gmail.com,johan.jasin@ung.ac.id
}

\begin{abstract}
Abstrak
Penelitian ini bertujuan untuk mengetahui dan menganalisis secara mendalam mengenai esensi dari pengaturan peraturan daerah yang bernuansa syariah dan konsep pembentukan peraturan daerah bernuansa syariah yang sejalan dengan otonomi daerah. Penelitian ini menggunakan jenis penelitian hukum normatif yang didukung dengan data primer yang berorientasi pada pendekatan perundangan-undangan dan Pendekatan kasus yang dilakukan dengan cara menganalisis hasil penelitian/studi yang mendapatkan data deskriptif analitis. Hasil penelitian ini menunjukkan bahwa: (1) Esensi Perda bernuansa syariah mempunyai makna dan memperhatikan materi muatan yang mengandung unsurunsur atau nilai-nilai adat istiadat dan norma-norma agama. Sehingga dalam yuridis formal, dapat dipahami Perda bernuansa syariah dapat dirumuskan sepanjang tidak bertentangan dengan Pancasila dan Undang-Undang Dasar Negara Republik Indonesia tahun 1945. (2) Konsep Perda yang bernuansa syariah sejalan dengan otonomi daerah, apabila dalam kaidah penyusunan Perda memenuhi unsur atau syarat yang sesuai dengan semangat pembangunan otonomi daerah yang memperhatikan kepentingan umum dan ketentuan hukum yang berlaku.
\end{abstract}

Kata Kunci: Validitas Peraturan daerah Bernuansa Syari'ah, Otonomi Daerah.

\begin{abstract}
This study aims to find out and analyze in depth the essence of the regulation of shariabased regional regulations and the concept of sharia-based regional regulation formation that is in line with regional autonomy. This research uses normative legal research that is supported by primary data which is oriented towards the statutory approach and case approach which is carried out by analyzing the results of research / studies that obtain descriptive analytical data. The results of this study indicate that: (1) Essence of sharia-nuanced local regulations have meaning and pay attention to material content that contains elements or values of customs and religious norms. So in formal juridical terms, it can be understood that sharia-based laws can be formulated as long as they are not in conflict with the Pancasila and the 1945 Constitution of the Republic of Indonesia. (2) The concept of Sharia-based Regional Regulations is in line with regional autonomy, if in the rules of drafting the Regional Regulations meet the elements or conditions in accordance with the spirit of regional autonomy development that takes into account the public interest and applicable legal provisions.
\end{abstract}

Keywords: Validity of Shari'ah Regulations, Regional Autonomy. 


\begin{tabular}{llrr}
\hline \hline Volume: & 2 & E-ISSN: & $2655-1942$ \\
Number: & 2 & Terbitan: & Oktober 2019 \\
Page $:$ & $168-182$ & & \\
\hline
\end{tabular}

\section{A. Pendahuluan}

Otonomi daerah dapat dimaknai dan dicermati dari berbagai perspektif, baik dari politik pemerintahan, aspek ekonomi, khususnya pada aspek hukum. Hal ini tergantung bagaimana pandangan terhadap permasalahan otonomi daerah. Dalam sudut pandang yang berhubungan dengan urusan pemerintahan dimaknai sebagai refleksi kebijakan pemerintah yang menjadi dasar legitimasi kekuasan daerah untuk mengatur masyarakatnya. Hal ini dilegitimasi oleh konstitusi, kemudian dijabarkan oleh instrumen hukum sampai kepada pengaturan khusus yang bersifat lokal. Sebagai sebuah upaya pengelolaan pemerintahan, legitimasi dijadikan sebagai bingkai yang dipandang sebagai refleksi hubungan antara Pemerintah Pusat dan Pemerintah Daerah. Legitimasi nya adalah memberi keleluasaan kepada daerah untuk mengembangkan atau mengurus pemerintahan daerah yang orientasinya pada peningkatan kesejahteraan rakyat di daerah.

Menurut para pakar yang mendalami masalah otonomi umumnya sepakat bahwa istilah, yang kemudian berkembang menjadi konsep otonomi itu berasal dari bahasa Yunani autos yang berarti sendiri dan namos yang berarti undangundang atau aturan tertulis dalam arti dibuat oleh lembaga yang punya kewenangan untuk itu ${ }^{1}$. Jika dipadukan dengan kata daerah (menjadi otonomi daerah) maka definisi ini dapat berkembang menjadi daerah mengatur atau memerintah sendiri. Pengertian ini tidaklah berarti sebagai kemerdekaan suatu daerah atas pemerintahan pusat, melainkan lebih dimaksudkan kepada kemandirian atau kebebasan suatu daerah untuk mengatur sendiri pemerintahan di daerahnya.

Dalam perspektif kewenangan, otonomi daerah dapat didefinisikan sebagai kewenangan yang secara mandiri dimiliki oleh suatu daerah, hal ini dimaknai mengandung muatan kewenangan untuk mengatur dan mengurus rumah tanggga sendiri. Kemandirian ini sangat dibutuhkan terutama untuk mengakomodasikan heterogenitas, bahkan multi heterogenitas pada setiap daerah.

\footnotetext{
${ }^{1}$ Samsul Wahidin, Hukum Pemerintahan Daerah, PENDULUM Otonomi Daerah Dari Masa KeMasa, Pustaka Pelajar, Yogyakarta, hal 3
} 


\begin{tabular}{|c|c|c|c|}
\hline Volume: & 2 & E-ISSN: & $2655-1942$ \\
\hline Number: & 2 & Terbitan: & Oktober 2019 \\
\hline Page : & $168-182$ & & \\
\hline
\end{tabular}

Agar lebih dipahami mengenai arti otonomi daerah, kita bisa merujuk kepada pendapat beberapa ahli tentang daerah otonom. Menurut Vincent Lemius, definisi otonomi daerah adalah suatu kebebasan atau kewenangan dalam membuat suatu keputusan politik maupun administrasi yang sesuai dengan yang ada di dalam peraturan perundang-undangan. Sedangkan menurut Syarif Saleh, pengertian otonomi daerah adalah suatu hak untuk mengatur serta memerintah daerah sendiri dimana hak tersebut ialah hak yang diperoleh dari suatu pemerintah pusat. Lebih lanjut Sunarsip memberikan pengertian bahwa otonomi daerah adalah wewenang daerah untuk mengurus dan mengatur semua kepentingan masyarakat menurut prakarsa sendiri yang berlandaskan pada aspirasi masyarakat sesuai dengan peraturan perundang-undangan. ${ }^{2}$

Perjalanan panjang mengenai pengaturan tentang Pemerintahan Daerah, telah melahirkan berbagai produk Peraturan Perundang-undangan, antara lain Undang-Undang Nomor 1 Tahun 1945, Undang-Undang Nomor 22 Tahun 1948, Undang-Undang Nomor 1 Tahun 1957, Penetapan Presiden Nomor 6 Tahun 1959, Undang-Undang Nomor 18 Tahun 1965, Undang-Undang Nomor 5 Tahun 1974, Undang-Undang Nomor 22 Tahun 1999, Undang-Undang Nomor 32 Tahun 2004, dan terakhir Undang-Undang Nomor 23 Tahun 2014.

Secara normatif Undang-Undang tersebut telah mampu mengikuti perkembangan perubahan kepemerintahan daerah sesuai zamannya. Secara empiris Undang-Undang tersebut dalam penyelenggaraan pemerintahan daerah memberikan implikasi terhadap kedudukan dan peran formal kekuasaan eksekutif dan kekuasaan legislatif daerah.

Sejalan dengan diberlakukannya Undang-undang Nomor 23 Tahun 2014 tentang Pemerintahan Daerah, memberikan definisi otonomi daerah sebagai berikut: hak, wewenang, dan kewajiban daerah otonom untuk mengatur dan mengurus sendiri Urusan Pemerintahan dan kepentingan masyarakat setempat dalam sistem Negara Kesatuan Republik Indonesia. Kemudian prinsip otonomi daerah itu sendiri menggunakan prinsip otonomi seluas-luasnya dalam arti daerah

\footnotetext{
${ }^{2}$ https://www.maxmanroe.com/vid/umum/pengertian-otonomi-daerah.html
} 


\begin{tabular}{llrr}
\hline Volume: & 2 & E-ISSN: & $2655-1942$ \\
Number: & 2 & Terbitan: & Oktober 2019 \\
Page : & $168-182$ & & \\
\hline
\end{tabular}

diberikan kewenangan mengurus dan mengatur semua urusan pemerintahan di luar yang menjadi urusan pemerintah yang ditetapkan dalam undang-undang ini. Daerah memiliki kewenangan membuat kebijakan daerah untuk memberi pelayanan, peningkatan peran serta, prakarsa, dan pemberdayaan masyarakat yang bertujuan pada peningkatan kesejahteraan rakyat. $^{3}$

Perbedaan penafsiran dalam analisis kajian otonomi daerah dikalangan para ahli, baik pengertian otonomi itu sendiri maupun prinsip-prinsip dalam pelaksanaan otonomi daerah. Otonomi daerah merupakan esensi pelaksanaan pemerintahan yang desentralistik, namun dalam perkembangan otonomi daerah, selain mengandung arti zelfwetgeving (membuat Perda), juga mencakup zelfbestuur (pemerintahan sendiri. ${ }^{4}$

Apabila merujuk kepada otonomi daerah yang ada, dapat dilihat perbedaan antara pemberian otonomi kepada daerah Provinsi Gorontalo dan Provinsi Aceh. Daerah otonomi diartikan sebagai kesatuan masyarakat hukum yang mempunyai batas-batas wilayah, yang berwenang mengatur dan mengurus urusan pemerintahan dan kepentingan masyarakat setempat menurut prakarsa sendiri, berdasarkan aspirasi masyarakat dalam sistem Negara Kesatuan Republik Indonesia. Berdasarkan rumusan tersebut, dalam daerah otonom terdapat unsur-unsur sebagai berikut:

a) Unsur batas wilayah, sebagai kesatuan masyarakat sadar hukum, batas suatu wilayah adalah sangat menentukan untuk kepastian hukum, bagi pemerintah dan masyarakat dalam melakukan interaksi hukum.

b) Unsur pemerintahan, eksistensi pemerintahan di daerah, didasarkan atas legitimasi undang-undang yang memberikan kewenangan kepada pemerintahan daerah, untuk menjalankan urusan pemerintahan yang berwenang mengatur berdasarkan kreativitas nya sendiri.

\footnotetext{
3 Widjaja, Penyelenggaraan Otonomi Daerah di Indonesia. Jakarta : PT Raja Grafindo Persada, 2007, hlm 133

4 Agussalim Andi, Pemerintahan Daerah Kajian: Politik dan Hukum, Bogor: Ghalia Indonesia, 2007. hlm 108 .
} 


\begin{tabular}{llrr}
\hline \hline Volume: & 2 & E-ISSN: & $2655-1942$ \\
Number: & 2 & Terbitan: & Oktober 2019 \\
Page $:$ & $168-182$ & & \\
\hline
\end{tabular}

c) Unsur masyarakat, masyarakat sebagai elemen pemerintahan daerah merupakan kesatuan masyarakat hukum. ${ }^{5}$

Hal ini berbeda dengan pemberian otonomi khusus kepada daerah lain misalnya Provinsi Aceh. Berdasarkan Undang-Undang Nomor 18 Tahun 2001 tentang Otonomi Khusus Bagi Provinsi Daerah Istimewa Aceh sebagai Provinsi Nanggroe Aceh Darussalam, dan Undang-Undang Nomor 11 Tahun 2006 tentang Pemerintahan Aceh. Dari dasar menimbang Undang-Undang Nomor 18 Tahun 2001 dan Undang-Undang Nomor 11 Tahun 2006 di Nanggroe Aceh Darussalam ini dapat dilihat kriteria dalam pemberian otonomi khusus bagi Nanggroe Aceh Darussalam. Kriteria pemberian otonomi khusus yang dikelompokkan dalam beberapa bagian diantaranya:

1) Dalam hal historis, yakni mendapatkan pengakuan khusus dari negara karena asal usul kesejarahan suatu daerah.

2) Dalam hal politik diantaranya:

a. mendapatkan pengakuan khusus dari negara karena untuk mengurangi konflik berkepanjangan yang terjadi di dalam daerah, baik Suku, Ras, Agama dan lainnya.

b. mendapatkan pengakuan khusus dari negara agar daerah tidak memisahkan diri dari Negara Kesatuan Republik Indonesia atau dengan kata lain menjaga keutuhan Negara Kesatuan Republik Indonesia.

3) Dalam hal sosial-kultural diantaranya:

a. mendapatkan pengakuan khusus dari negara karena untuk menghargai budaya kental dari suatu daerah, seperti Nanggroe Aceh Darussalam (NAD) yang sangat kental kebudayaan islam dipergunakan dalam kehidupan sehari-hari.

b. mendapatkan pengakuan khusus dari negara karena adanya kekhususan di bidang tertentu pada daerah tersebut seperti pariwisata dan letak geografis suatu daerah.

5 Siswanto Sunarno, Hukum Pemerintahan Daerah di Indonesia, Sinar Grafika, Jakarta, 2009. hlm: 6-7. 


\begin{tabular}{llrr}
\hline \hline Volume: & 2 & E-ISSN: & $2655-1942$ \\
Number: & 2 & Terbitan: & Oktober 2019 \\
Page $:$ & $168-182$ & & \\
\hline
\end{tabular}

4) Dalam hal ekonomi, yakni mendapatkan pengakuan khusus dari negara untuk membantu ketertinggalan suatu daerah dengan daerah lainnya, seperti Papua adalah daerah yang kaya, namun tertinggal dalam banyak bidang seperti ekonomi, kesejahteraan masyarakat, pendidikan, kesehatan dan lainnya. ${ }^{6}$

Pengaturan mengenai otonomi khusus bagi daerah tertentu dalam Negara Kesatuan Republik Indonesia, mencakup segala segi, sehingga setiap daerah dapat menuntut suatu kekhususan, semata-mata berdasarkan faktor-faktor tertentu tanpa suatu kriteria umum yang ditetapkan dalam undang-undang. Apalagi jika kekhususan itu mengandung muatan privelege tertentu yang tidak dimiliki daerah lain. ${ }^{7}$ Hal ini disebabkan aspirasi masyarakat di daerah itu beragam, karena potensi, situasi dan keadaan di setiap daerah tidak sama atau satu dengan yang lainnya.

Memperhatikan perbedaan yang mendasar antara berbagai peraturan perundang-undangan yang ada dan pernah ada, maka masalah pelaksanaan otonomi daerah, baik daerah otonomi maupun otonomi khusus sangat penting karena setiap pengaturan yang menyangkut hubungan Pusat dan Daerah akan bersangkutan langsung dengan upaya memelihara keutuhan negara kesatuan. ${ }^{8}$

Berbagai peraturan perundang-undangan yang pernah berlaku dan sedang berlaku, tampaknya dipandang belum sepenuhnya mencerminkan dan menemukan corak dalam pelaksanaan otonomi daerah yang tepat dan wajar. Oleh karena itu, untuk menemukan dan mengembangkan konsepsi hukum tersebut diperlukan suatu penyelidikan dan pengkajian mendalam mengenai "Validitas Perda Yang Bernuansa Syariah Dalam Bingkai Otonomi Daerah (Between Hope and Reality) As an Example Gorontalo dan Aceh"

\footnotetext{
6 Dalam buku Rusdianto Sesung, Hukum Otonomi Daerah Negara Kesatuan, Daerah Istimewa dan Daerah Otonomi Khusus, Op.Cit.., Hlm: 105-106.

7 Bagir Manan, Menyongsong Fajar Otonomi Daerah, Pusat Studi Hukum, Yogyakarta.

8 Bagir Manan, Hubungan Antara Pusat dan Daerah Menurut UUD 1945, Pustaka Sinar Harapan, Jakarta, hlm. 20.
} 


\begin{tabular}{llrr}
\hline \hline Volume: & 2 & E-ISSN: & $2655-1942$ \\
Number: & 2 & Terbitan: & Oktober 2019 \\
Page $:$ & $168-182$ & & \\
\hline
\end{tabular}

\section{B. Pembahasan}

\section{Esensi dari pengaturan dalam Perda yang bernuansa syariah}

Provinsi Gorontalo dibentuk berdasarkan Undang-Undang Republik Indonesia Nomor 38 Tahun 2000 tentang Pembentukan Provinsi Gorontalo, dengan Ibukota Provinsi Gorontalo adalah Kota Gorontalo (atau dengan nama lain Kota Hulontalo) yang dikenal dengan julukan Kota Serambi Madinah. Dalam proses sejarah pembentukan Provinsi Gorontalo, Cornelis van Vollenhoven menempatkan daerah Gorontalo pada salah satu wilayah yang terdiri dari 19 wilayah hukum adat di Indonesia. Dengan ditempatkannya wilayah Gorontalo ke dalam golongan daerah yang memiliki aturan-aturan, norma-norma, dan nilainilai serta tatanan hukum sendiri dalam pengaturan warganya, dapat diartikan bahwa orang Gorontalo pada hakikatnya telah dinilai oleh bangsa asing sebagai suatu kelompok masyarakat yang memiliki peradaban. ${ }^{9}$ Secara historis Gorontalo dikenal sebagai salah satu daerah yang berhasil menjadikan agama islam sebagai identitas utama dari bangunan budaya dan perkembangan masyarakatnya. Dimana agama dengan adat istiadat saling menyatu yang dikenal dengan "Adat bersendikan Syara' dan Syara' bersendikan Kitabullah”.

Menurut van Vollenhoven, tingginya nilai dari labelisasi terhadap adatistiadat dilihat sebagai suatu pencerminan atau penjelmaan dari kepribadian suatu suku-bangsa (etnis). Hal ini telah menjadi semacam prestise, dan sekaligus sebagai identitas masyarakat Gorontalo dan patut kiranya dilestarikan oleh orang Gorontalo selaku pendukung kebudayaan tersebut. Perbedaan adat-istiadat dari masing-masing daerah merupakan ciri terpenting yang dapat memberikan suatu identitas kepada suku-bangsa yang bersangkutan. ${ }^{10}$ Berangkat dari tuntutan akan sebuah otonomi yang lebih luas, dalam korelasi antara identitas etnik Provinsi Gorontalo dan pembentukan Perda yang bernuansa syariah di Provinsi Gorontalo.

Adapun nilai yang terkandung dalam falsafah masyarakat Gorontalo Adat bersendikan Syara' dan Syara' bersendikan Kitabullah mengandung syarat

9 Mahyudindamis, 2010. kritik terhadap falsafah "adat-bersendikan-syara'-syara'-bersendikankitabullah"di Gorontalo. Wordpress

${ }_{10}$ Ibid.kritik terhadap falsafah "adat-bersendikan-syara'-syara'-bersendikan-kitabullah" di Gorontalo.Wordpress 


\begin{tabular}{llrr}
\hline \hline Volume: & 2 & E-ISSN: & $2655-1942$ \\
Number: & 2 & Terbitan: & Oktober 2019 \\
Page $:$ & $168-182$ & & \\
\hline
\end{tabular}

akan makna dan etika hukum yang rasional. Kehidupan masyarakat Gorontalo yang memang kental dengan adat istiadatnya yang bernapaskan Islam, sedikit atau banyak telah memberikan kontribusi dalam proses terbentuknya Provinsi Gorontalo. Nilai-nilai adat istiadat ini merupakan norma atau tata kelakuan yang tumbuh, berkembang, dan dijunjung tinggi oleh masyarakat Gorontalo secara turun-temurun sehingga kuat integrasi nya dengan pola perilaku masyarakat yang ada.

Sementara di sisi lain, dampak bagi keberlakuan nilai-nilai adat dan norma agama dalam kehidupan bersama masyarakat Gorontalo sangat terasa sehingga perlu dipikirkan pelestarian bahkan pengembangan nilai-nilai tersebut dalam bentuk regulasi/pengaturan hukum khususnya bagi masyarakat Gorontalo, sehingga dapat membawa kebaikan dan kesejahteraan bagi kehidupan masyarakat. Lahirnya Perda yang bernuansa syariah dapat dikatakan merupakan sebuah inovasi untuk menjaga masyarakat menjadi tertib baik dilihat dari sisi hubungan sesama individu, hingga keterjaminan moral individu tersebut dalam kehidupan bermasyarakat.

Perda sebagai produk hukum di daerah, hendaknya mampu mengarahkan masyarakat daerah ke arah yang lebih baik dan mampu mengayomi masyarakat. Jika disimak pendapat dari Meuwissen yang menyatakan bahwa hukum mempunyai keberlakuannya apabila mampu berlaku secara sosiologis, berlaku secara yuridis dan berlaku secara moral. ${ }^{11}$ Perda yang baik hendaknya mencerminkan aspek filosofis yang berkaitan dengan prinsip bahwa Perda akan menjamin keadilan, sosiologis berkaitan dengan harapan bahwa perda yang dibentuk merupakan keinginan masyarakat daerah, dan yuridis berkaitan dengan harapan bahwa perda memenuhi dan menjamin kepastian hukum seperti halnya pembentukan Undang-undang.

Secara esensi Perda bernuansa syariah adalah peraturan daerah biasa, dimana materi muatannya mengandung unsur-unsur atau nilai-nilai adat istiadat dan norma-norma agama. Hal ini semestinya tidak bisa dipandang sebelah mata,

\footnotetext{
11 Meuwissen, Pengembangan Hukum, Ilmu Hukum, Teori Hukum, dan Filsafat Hukum, terj. Meuwissen. Bandung: Refika Aditama, 2007. hlm. 46-47
} 


\begin{tabular}{llrr}
\hline \hline Volume: & 2 & E-ISSN: & $2655-1942$ \\
Number: & 2 & Terbitan: & Oktober 2019 \\
Page $:$ & $168-182$ & & \\
\hline
\end{tabular}

dalam arti sudut sempit melihat perda semacam ini menghalangi hak warga beragama minoritas atau dianggap diskriminatif karena memiliki implikasi pembatasan aktivitas warga minoritas. Akan tetapi, lebih dimaknai sebagai keinginan dan kebutuhan masyarakat, khususnya masyarakat Gorontalo dalam menjaga dan membudayakan sendi-sendi tatanan kehidupan beragama dan adat masyarakat Gorontalo yang dikenal sangat religius, karena subtansi Perda lebih ke arah pengendalian, pencegahan, serta peningkatan moral dan akhlak. Secara yuridis formal, dapat dipahami Perda bernuansa syariah dapat dirumuskan sepanjang tidak bertentangan dengan Pancasila dan Undang-Undang Dasar Negara Republik Indonesia tahun 1945.

\section{Konsep pembentukan Perda yang bernuansa syariah sejalan dengan otonomi daerah.}

Dalam tataran konsep, Perda dapat diklasifikasikan menjadi dua bagian, yaitu: (1) Perda syariah dengan status otonomi khusus atau yang sering disebut dengan istilah Qanun, dan (2) Perda yang bernuansa syariah dengan status otonomi biasa. Perda syariah dengan status otonomi khusus, misalnya Provinsi Aceh jika dilihat dari tingkat konsistensi sistem hukum, jelas mempunyai payung hukum dengan adanya Undang-Undang Nomor 18 Tahun 2001 tentang Otonomi Khusus Bagi Provinsi Daerah Istimewa Aceh sebagai Provinsi Nanggroe Aceh Darussalam, dan Undang-Undang Nomor 11 Tahun 2006 tentang Pemerintahan Aceh.

Dari dasar menimbang Undang-Undang Nomor 18 Tahun 2001 dan Undang-Undang Nomor 11 Tahun 2006 di Nanggroe Aceh Darussalam ini dapat dilihat beberapa kekhususan lainnya yang membuat Provinsi Nanggroe Aceh Darussalam dengan daerah lainnya sebagaimana yang terdapat di dalam UndangUndang Nomor 11 Tahun 2006 tentang Pemerintahan Aceh di ataranya:

a) Pembagian daerah di Aceh yang dibagi ke dalam kabupaten/kota, kecamatan, mukim, kelurahan dan gampong. Mukim merupakan kesatuan masyarakat hukum di bawah kecamatan yang terdiri atas gabungan beberapa gampong. Sedangkan kelurahan dan gampong adalah kesatuan masyarakat hukum yang berada di bawah mukim. 


\begin{tabular}{llrr}
\hline \hline Volume: & 2 & E-ISSN: & $2655-1942$ \\
Number: & 2 & Terbitan: & Oktober 2019 \\
Page $:$ & $168-182$ & & \\
\hline
\end{tabular}

b) Rencana persetujuan internasional yang berkaitan langsung dengan Pemerintahan Aceh yang dibuat oleh Pemerintah dilakukan dengan konsultasi dan pertimbangan DPRA. Pemerintahan Aceh dapat mengadakan kerja sama dengan lembaga atau badan di luar negeri kecuali yang menjadi kewenangan Pemerintah. Dalam naskah kerja sama tersebut dicantumkan frase Pemerintah Aceh sebagai bagian dari Negara Kesatuan Republik Indonesia. Serta Pemerintah Aceh dapat berpartisipasi secara langsung dalam kegiatan seni, budaya dan olah raga internasional.

c) Rancangan pembentukan undang-undang oleh Dewan Perwakilan Rakyat yang berkaitan langsung dengan Pemerintah an Aceh dilakukan dengan konsultasi dan pertimbangan DPRA.

d) Kebijakan administratif yang berkaitan langsung dengan Pemerintahan Aceh yang akan dibuat oleh Pemerintah dilakukan dengan konsultasi dan pertimbangan Gubernur.

e) Penduduk Aceh dapat membentuk partai politik lokal yang memiliki hak antara lain; mengikuti Pemilu untuk memilih anggota DPRA dan DPRK; mengusulkan pasangan calon Gubernur dan Wakil Gubernur, calon Bupati dan Wakil Bupati, serta calon Wakil Walikota di Aceh.

f) Di Aceh terdapat pengadilan Syariat Islam yang dilaksanakan oleh sebuah Mahkamah Syariah, yang terdiri dari Mahkamah Syariah Aceh sebagai pengadilan tingkat banding dan Mahkamah Syariah Kabupaten/Kota sebagai pengadilan tingkat pertama. Mahkamah Syariyah berwenang memeriksa, mengadili, memutus dan menyelesaikan perkara yang meliputi bidang ahwal al-syakhsiyah (hukum keluarga), muamalah (hukum perdata) dan jinayah (hukum pidana) yang didasarkan atas syariyat Islam dengan hukum acara yang ditetapkan berdasarkan Qanun.

g) Produk hukum sejenis peraturan daerah (perda) di Aceh disebut dengan istilah Qanun. Terdapat dua macam Qanun, yaitu Qanun Aceh yang disahkan oleh Gubernur setelah mendapatkan persetujuan bersama dengan DPRA dan Qanun Kabupaten/Kota ditetapkan oleh Bupati/ Walikota setelah mendapatkan persetujuan bersama DPRK. Qanun dibentuk dalam rangka 


\begin{tabular}{rlrr}
\hline \hline Volume: & 2 & E-ISSN: & $2655-1942$ \\
Number: & 2 & Terbitan: & Oktober 2019 \\
Page : & $168-182$ & & \\
\hline
\end{tabular}

penyelenggaraan Pemerintahan Aceh, Pemerintahan Kabupaten/Kota dan penyelenggaraan tugas pembantuan. Qanun dapat memuat ancaman pidana atau denda lebih dari 6 (enam) bulan kurungan dan/atau denda paling banyak Rp. 50.000.000,00 (lima puluh juta rupiah). Bahkan Qanun mengenai jinayah (hukum pidana) dapat menentukan jenis dan bentuk ancaman pidana tersendiri.

h) Pemerintah Aceh dan Pemerintah Kabupaten/Kota dapat membentuk lembaga, badan dan/atau komisi dengan persetujuan DPRA/DPRK. DI Aceh terdapat institusi atau lembaga yang tidak terdapat di daerah-daerah lainnya, seperti Majelis Permusyawaratan Ulama (MPU) yang merupakan mitra kerja Pemerintah Aceh, Kabupaten/Kota dan DPRA/DPRK, Lembaga Wali Nanggroe dan Lembaga Adat, Pengadilan Hak Asasi Manusia, Komisi Kebenaran dan Rekonsiliasi dan Unit Polisi Wilayah Hisbah sebagai bagian dari Satuan Polisi Pamong Praja, sebagai penegak Syariyat Islam. ${ }^{12}$

Berdasarkan Undang-Undang Nomor 23 tahun 2014, pemerintah daerah mempunyai hak untuk membuat peraturan daerah. Hal ini berbeda dengan pembentukan Qanun di Provinsi Aceh dengan status otonomi khusus, dapat menerapkan Perda syariah atau asas Islam secara menyeluruh di Provinsi Nanggroe Aceh Darussalam .

Oleh karena itu, pemahaman Perda yang bernuansa syariah dengan status otonomi biasa relatif bertabrakan dengan Undang-Undang pemerintahan daerah sebagaimana disebut di atas. Karena menurut Undang-Undang tentang Pemerintahan Daerah yang berlaku saat ini, masalah agama tidak dapat diatur oleh pemerintah daerah dan menjadi domain absolut bagi pemerintahan pusat. Namun, perlu dijelaskan bahwa masalah agama yang dimaksud dalam Undang-Undang tersebut sebagaimana yang tertuang dalam penjelasan Pasal 10 Ayat (1) huruf F adalah misalnya menetapkan hari libur keagamaan yang berlaku secara nasional,

12 Dalam buku Rusdianto Sesung, Hukum Otonomi Daerah Negara Kesatuan, Daerah Istimewa dan Daerah Otonomi Khusus, Op.Cit.., Hlm: 105-106. 


\begin{tabular}{rlrr}
\hline \hline Volume: & 2 & E-ISSN: & $2655-1942$ \\
Number: & 2 & Terbitan: & Oktober 2019 \\
Page : & $168-182$ & & \\
\hline
\end{tabular}

memberikan pengakuan terhadap keberadaan suatu agama, menetapkan kebijakan dalam penyelenggaraan kehidupan keagamaan, dan sebagainya. Kemudian daerah dapat memberikan hibah untuk penyelenggaraan kegiatan-kegiatan keagamaaan sebagai upaya meningkatkan keikutsertaan daerah dalam menumbuh kembangkan kehidupan beragama, misalnya penyelenggaraan Musabaqah Tilawatil Qur'an $(M T Q)$, pengembangan bidang pendidikan keagamaan, dan sebagainya. ${ }^{13}$

Untuk memperjelas permasalahan mengenai konsep Perda yang bernuansa syariah, perlu dipahami makna yang terkandung dalam UndangUndang Nomor 23 tahun 2014 tentang Pemerintahan Daerah. Dalam penjelasan umum disebutkan bahwa Perda sebagai dasar hukum bagi Daerah dalam menyelenggarakan Otonomi Daerah sesuai dengan kondisi dan aspirasi masyarakat serta kekhasan dari Daerah tersebut. Perda yang dibuat oleh Daerah hanya berlaku dalam batas-batas yurisdiksi Daerah yang bersangkutan. Walaupun demikian Perda yang ditetapkan oleh Daerah tidak boleh bertentangan dengan ketentuan peraturan perundang-undangan yang lebih tinggi tingkatannya sesuai dengan hierarki peraturan perundang-undangan. Di samping itu Perda sebagai bagian dari sistem peraturan perundang-undangan tidak boleh bertentangan dengan kepentingan umum sebagaimana diatur dalam kaidah penyusunan Perda. $^{14}$

Berdasarkan penjelasan tersebut, secara eksplisit ditegaskan bahwa konsep pembentukan Perda seharusnya tidak boleh bertentangan dengan ketentuan peraturan perundang-undangan yang lebih tinggi dan bertentangan dengan kepentingan umum. Menurut I Gde Pantja Astawa, yang merumuskan tolok ukur kepentingan umum dengan indikator sebagai berikut:

1) kepentingan daerah yang bersangkutan/setempat, ialah sejauh mana partisipasi masyarakat dilibatkan ke dalam proses pembentukan peraturan daerah; dan

\footnotetext{
13 Dalam Penjelasan Pasal 10 Ayat (1) huruf "f" UU Nomor 23 Tahun 2014 Tentang Pemerintahan Daerah.

${ }^{14}$ Dalam Penjelasan Umum angka 8, UU Nomor 23 Tahun 2014 Tentang Pemerintahan Daerah.
} 


\begin{tabular}{llrr}
\hline \hline Volume: & 2 & E-ISSN: & $2655-1942$ \\
Number: & 2 & Terbitan: & Oktober 2019 \\
Page $:$ & $168-182$ & & \\
\hline
\end{tabular}

2) kepentingan daerah lain dan kepentingan nasional, berdasarkan otonomi daerah, bahwa pelaksanaan otonomi harus sesuai dengan konstitusi negara, sehingga tetap terjamin hubungan yang serasi antara pusat dan daerah serta antar daerah; bertentangan dengan keputusan-keputusan pemerintah yang lebih atas yang tidak tergolong sebagai peraturan perundang-undangan. ${ }^{15}$

Lebih lanjut terhadap tolok ukur bertentangan dengan peraturan perundang-undangan yang lebih tinggi tingkatannya, Wiyono berpendapat seyogianya memang perlu diperluas menjadi "bertentangan dengan hukum", dengan kriterianya yaitu:

1) Mencermati dengan saksama asas-asas penyusunan peraturan daerah; dan

2) Syarat prosedural, yang meliputi mekanisme pembentukan peraturan daerah yang diperintahkan peraturan perundang-undangan yang berlaku. ${ }^{16}$

Menilik teori validitas atau validitas hukum mengajarkan bagaimana dan apa saja kondisinya sehingga aturan hukum menjadi sah dan sah, sehingga dapat diterapkan pada masyarakat, jika perlu dengan upaya paksa, yaitu aturan hukum yang memenuhi persyaratan sebagai berikut:

1) Aturan hukum harus dirumuskan menjadi berbagai bentuk aturan formal, seperti dalam bentuk artikel dari Konstitusi, Hukum dan berbagai bentuk peraturan lainnya, aturan internasional seperti perjanjian, konvensi, atau setidaknya dalam bentuk bea cukai.

2) Peraturan formal harus dibuat secara hukum, misalnya jika dalam bentuk Undang-undang harus dibuat oleh parlemen bersama dengan pemerintah, dalam bentuk Peraturan Daerah harus dibuat oleh Dewan Perwakilan Rakyat Daerah bersama dengan Pemerintah Daerah.

3) Secara hukum, aturan hukum ini tidak dapat dibatalkan.

\footnotetext{
15 Akhmad Nikhrawi Hamdie, Keabsahan Peraturan Daerah Dalam Rangka Penyelenggaraan Otonomi Daerah, Volume 2, No. 1, Mei 2017, hlm.57.

16 Ibid. Keabsahan Peraturan Daerah Dalam Rangka Penyelenggaraan Otonomi Daerah, Volume 2, No. 1, Mei 2017, hlm.59-60.
} 


\begin{tabular}{llrr}
\hline \hline Volume: & 2 & E-ISSN: & $2655-1942$ \\
Number: & 2 & Terbitan: & Oktober 2019 \\
Page $:$ & $168-182$ & & \\
\hline
\end{tabular}

4) Untuk aturan formal ini tidak ada cacat yuridis lainnya. Misalnya, tidak bertentangan dengan peraturan yang lebih tinggi.

5) Negara hukum harus diterapkan oleh lembaga penegak hukum, seperti pengadilan, polisi, jaksa.

6) Aturan hukum harus diterima dan dipatuhi oleh masyarakat.

7) Negara hukum harus sesuai dengan jiwa bangsa yang bersangkutan. ${ }^{17}$

Oleh karena itu, dapat dikatakan bahwa hukum yang tidak dibuat dengan benar, atau hukum yang tidak dibuat oleh pihak yang tepat, atau hukum yang tidak diterima oleh masyarakat, atau hukum yang tidak adil, bukan hukum. Perda yang baik hendaknya mencerminkan aspek filosofis yang berkaitan dengan prinsip bahwa perda akan menjamin keadilan, sosiologis berkaitan dengan harapan bahwa perda yang dibentuk merupakan keinginan masyarakat daerah, dan yuridis berkaitan dengan harapan bahwa perda memenuhi dan menjamin kepastian hukum. Senada dengan hal tersebut, meskipun tidak ada perda yang secara eksplisit menyebut dirinya sebagai Perda Syariah, namun isinya secara implisit bernuansa syariah atau sesuai dengan nilai-nilai budaya dan norma agama yang berlaku dalam masyarakat.

\section{Penutup}

Dari uraian di atas, disampaikan bahwa esensi Perda bernuansa syariah adalah peraturan daerah biasa, dimana materi muatannya mengandung unsurunsur atau nilai-nilai adat istiadat dan norma-norma agama. Khususnya masyarakat Gorontalo yang dikenal sangat religius, berhasil menjadikan agama dengan adat istiadat saling menyatu, yang dikenal dengan "Adat bersendikan Syara' dan Syara' bersendikan Kitabullah". Sehingga dalam yuridis formal, dapat dipahami Perda bernuansa syariah dapat dirumuskan sepanjang tidak bertentangan dengan Pancasila dan Undang-Undang Dasar Negara Republik Indonesia tahun 1945. Kemudian konsep Perda yang bernuansa syariah sejalan dengan otonomi

\footnotetext{
17 Munir Fuady, Great Theories (Grand Theory) in Law, Jakarta, Prenadamedia Group, 2013, hlm. 109
} 


\begin{tabular}{rlrr}
\hline Volume: & 2 & E-ISSN: & $2655-1942$ \\
Number: & 2 & Terbitan: & Oktober 2019 \\
Page : & $168-182$ & & \\
\hline
\end{tabular}

daerah, apabila dalam kaidah penyusunan Perda memenuhi unsur atau syarat yang sesuai dengan semangat pembangunan otonomi daerah yang memperhatikan kepentingan umum dan ketentuan hukum yang berlaku.

\section{DAFTAR PUSTAKA}

\section{Buku}

Agussalim Andi, 2007. Pemerintahan Daerah Kajian: Politik dan Hukum, Bogor: Ghalia Indonesia.

Akhmad Nikhrawi Hamdie, Keabsahan Peraturan Daerah Dalam Rangka Penyelenggaraan Otonomi Daerah, Volume 2, No. 1, Mei 2017.

Bagir Manan, 2005. Menyongsong Fajar Otonomi Daerah, Pusat Studi Hukum, Yogyakarta.

., Hubungan Antara Pusat dan Daerah Menurut UUD 1945, Pustaka Sinar Harapan, Jakarta.

Mahyudindamis, 2010. Kritik Terhadap Falsafah "Adat-bersendikan-syara'syara'-bersendikan-kitabullah”di Gorontalo. Wordpress

Meuwissen, 2007. Pengembangan Hukum, Ilmu Hukum, Teori Hukum, dan Filsafat Hukum, terj. Meuwissen. Bandung: Refika Aditama.

Munir Fuady, 2007. Great Theories (Grand Theory) in Law, Jakarta, Prenadamedia Widjaja, Penyelenggaraan Otonomi Daerah di Indonesia. Jakarta : PT Raja Grafindo Persada.

Rusdianto Sesung, 2013. Hukum Otonomi Daerah Negara Kesatuan, Daerah Istimewa dan Daerah Otonomi Khusus,.Group

Samsul Wahidin, Hukum Pemerintahan Daerah, PENDULUM Otonomi Daerah Dari Masa Ke-Masa, Pustaka Pelajar, Yogyakarta.

Siswanto Sunarno, 2009. Hukum Pemerintahan Daerah di Indonesia, Sinar Grafika, Jakarta.

Widjaja, 2007. Penyelenggaraan Otonomi Daerah di Indonesia. Jakarta : PT Raja Grafindo Persada.

\section{Undang-Undang}

Undang-Undang Nomor 23 Tahun 2014 tentang Pemerintah Daerah.

\section{Internet}

https://www.maxmanroe.com/vid/umum/pengertian-otonomi-daerah.html 